DOI: https://doi.org/10.47405/mjssh.v6i3.703

\begin{tabular}{|c|c|}
\hline 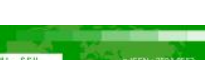 & Malaysian Journal of Social Sciences and Humanities (MJSSH) \\
\hline Malavsian Journal of & Volume 6, Issue 3, March 2021 \\
\hline $\begin{array}{l}\text { Humantites } \\
\text { (MJ. SSH })\end{array}$ & e-ISSN : 2504-8562 \\
\hline & $\begin{array}{l}\text { Journal home page: } \\
\text { www.msocialsciences.com }\end{array}$ \\
\hline
\end{tabular}

\title{
Exploring Alternative form of International Aid: A Study on Islamic Faith Based Organisation (IFBOs) Assistance in Gaza, Palestine
}

\author{
Ferooze Ali' ${ }^{1}$, Azmil Tayeb ${ }^{1}$ \\ ${ }^{1}$ School of Social Sciences, Universiti Sains Malaysia (USM), Malaysia \\ Correspondence: Ferroze Ali (ferooze@students.usm.my)
}

\begin{abstract}
International aid from the U. S, UK, and EU has always been constantly debated within the context the Occupied Palestinian Territories (oPt). The concern revolves around Western donors' strict political and economic-based conditions. Critiques focus on how these factors impede aid effectiveness in addressing the local Palestinian challenges under Israel's colonisation. The researcher argued, while this theme has been a defining feature of the academic debate for the past two decades, less research is apportioned towards exploring an alternative form of donorship. To be specific, the idea of seeking a new category of actor donor which might render aid in a more selfless, flexible, and democratic basis. To explore this potentiality, the researcher selected the IFBOs sector focusing on organisations from Malaysia, i.e. Malaysian Islamic Faith-Based Organisation (MFBOs). I dissected the policies of 7 MFBOs to gain insights into this sector's socio-economic aid in Gaza. I interviewed 13 policymakers. The overall outcome of this exploratory research suggested the MFBOs sector is generally more flexible and democratic in their policy conduct. Further research is also needed to expand this discourse.
\end{abstract}

Keywords: Islamic Faith Based Organisations, Islamic Altruistic Values, Sadaqah, Aid Conditions, FBOs, Gaza, Palestine

\section{Introduction}

International Aid has been one of the main pillars, which supports the Oslo Peace Process between Palestinian Authority (PA) and Israel since 1993. Main providers for international assistance under Oslo are the United States (US), the United Kingdom (UK) European Union (EU) World Bank, and United Nations (UN) (More 2008). These major international donors collectively have contributed nearly \$22.7 billion in aid since 1993. Sectors that are given particular attention by donor's aid money involved Palestine state-building assistance, health, and humanitarian, education, democracy and governance, private enterprise, water resources, agriculture, and infrastructure. Socio-economic assistance is equally provided to the grass-root segment to avoid a total collapse of Palestinian social system in different districts.

However, from the late 1990s up to the present-day circumstances, a growing consensus in the academic body, begin questioning aid from this sector. Research findings suggested Western donors' strict political and economic-based conditions impede aid effectiveness in addressing the actual Palestinian challenges under Israel's colonisation (Challand 2008; Hammami 1995; More 2008; 
Qarmout 2017; Taghdisi Rad, 2015; Shafi 2004; Sari Hanafi \& Linda Tabar, 2005). Various aspect of aid provision is layered with restrictive policies.

Notwithstanding the growing evidence, research into exploring alternative form of donorship, which could focus less on terms and conditions as opposed to recipients' interest, has taken on a reactive pace. As mentioned earlier, in addressing this gap - the researcher explored the Malaysian Islamic Faith Based (MFBOs) sector. This research specifically emphasised MFBOs that engaged in socioeconomic projects from 2009 to 2020.

\section{Literature Review}

One of the much-discussed areas revolves around the impact of Western donors' aid modalities on socio-economic projects and their recipients. The main cause has been the over bureaucratization of the latter's aid interaction mechanism. One could summarise such phenomenon occurs within the multifaceted aspect of project cycles of planning, financing implementation and evaluation. There are a few case scenarios worth examining.

For example, Western donors may set conditions on the type of recipients to engage with, during project planning. Sari Hanafi and Linda Tabar argued this selection is based upon (1) political eligibility, (2) sectoral eligibility, and (3) professional eligibility (Sari Hanafi \& Linda Tabar ,2005). For critiques, such conditional based interaction, discriminates the poorer or deserving sector. An impoverished village that is connected to Hamas or Islamic Jihad cell, for instance - could be sidelined to ensure political eligibility is observed. In different scenarios, a planning stage may include or stipulate complex technical writing conditions. As detailed by Challand (2008), lacking skills especially for non-professional rural PNGOs may lead to their disqualification from receiving aid. Rural PNGOs are the lifeline to the poor in West Bank and Gaza.

Another factor revolves around different approaches in aid financing. In various research work, it is recognised aid funding arrives with different procedural conditions. Grant is an example. According to Challand, a grant is often conditioned on a short-term basis. To him, this factor implies the lack of flexibility and capacity of grant modality in anticipating any advance financial needs ahead, by recipients (Challand, 2008). Grant may also come with political conditions. This impact is largely seen under the USAID Compete project in oPt. In early 2018, 7 socio-economic sectors involving Agribusiness, ICT, Tourism, Fish rearing, Stone \& Marble, Textile, and Furniture are selected for grant assistance. However, the grant aid was short-lived. The Trump Administration in January 2019 ceased all related grants when Palestinian President Abbas declined to take part in the U.S sponsored 'Deal of the Century' peace process (Al-Jazeera News Middle East, 2019). Funding to all these projects in these sectors was affected with 85 percent of USAID employees are laid off (Staff, 2019).

Implementing aid initiatives funded by Western donors have been described as bureaucratic. Tamer Qarmout, in his Gaza fieldwork, discovered some Western donors require the implementation of a strict procurement policy for recipients. Associate of Rural Development (ARD), which is the United States Aid (USAID) partner in Gaza - requires the purchase of any agriculture material from legal sources. Underground tunnels which are critical in their use, especially during prolong blockade by Israel and Egypt, could not be the source for procurement. Legal sources for ARD involves materials imported via Israeli and Egyptian checkpoints (Qarmout 2017).

Finally, is the aspect of evaluation and its strict linking to funding decision. As argued by Sari Hanafi and Linda Tabar (2005), the focus on such methodology may come at the cost of side-lining the aspect of learning from experiences, including failures. The researchers argued - this scenario is further compounded by the unwillingness of certain donor to share their insights or observation from any evaluation outcome. Here donors' action varies from total avoidance to only providing brief excerpts/brief details. Sari Hanafi and Linda Tabar (2005) emphasised how information sharing is vital, as inputs can be utilised to improve the learning curve not only for recipients but also donors. 


\section{Theoretical Framework}

As argued by Clarke, 'Element of faith' can be an essential part of a given FBO Humanitarian and Development charitable initiative (Clarke, 2008). Within Islamic donorship practice, 'elements of faith' can be categorically be separated between Islamic altruistic values and religious financing modalities. I will elaborate the element of Islam altruistic values first.

Islamic altruism and its associated values are often defined in a broad fashion. In this context, altruism is expressed through any Islamic values that motivate a selfless act (either through giving charity or other deeds) which can both benefit others and pleases God (Allah SWT).

Given the above framework, Islamic values which can be argued to push for an altruistic conduct during different aspect of social interaction are such as the idea of Rahmatan Lil Alamin (Mercy to all) Ikhlas (Sincerity), Ukhuwah (Solidarity), Ummah (Broader Community), Amanah (trustworthiness) or the notion of Huquq Al-Insan (Human Rights of the Oppressed) and Al-Adl (Justice). From my direct working experience with various MFBOs - some of these values are also generally articulated within this sector. The table 1 below, provides the list of different Islamic altruistic values which is generally within the constellation of Islamic Humanitarianism.

Table 1: Islamic Altruistic Values

\begin{tabular}{|c|c|c|}
\hline $\begin{array}{l}\text { Islamic Religious } \\
\text { Values/Modalities }\end{array}$ & Translated Meaning & Imbued principles \\
\hline Ijma & Consensus & $\begin{array}{l}\text { To strive in seeking a mutually agreed or } \\
\text { compromise solution to an issue }\end{array}$ \\
\hline Al-Adl & Enacting Justice & To seek justice for the oppressed \\
\hline Huquq Al-Insan & Human Rights & $\begin{array}{l}\text { To enact or champion for the rights of the } \\
\text { oppressed }\end{array}$ \\
\hline Al-Tawasaa'u & Inclusivity & $\begin{array}{l}\text { To ensure all parties are included in any } \\
\text { decision }\end{array}$ \\
\hline Al-Mussawah & Equality & $\begin{array}{l}\text { To ensure all human beings are treated with } \\
\text { equal measures and dignity }\end{array}$ \\
\hline Al-Dharuriyyat & State of Disaster & $\begin{array}{l}\text { The immediate need for unquestioning } \\
\text { empathy and assistance to ensure } \\
\text { survivability }\end{array}$ \\
\hline Shura & Council of Experts & $\begin{array}{l}\text { Shura stresses the idea of setting a proper } \\
\text { council and consultation among members } \\
\text { before decisions are made }\end{array}$ \\
\hline Musyawarah & Two-way discussion & $\begin{array}{l}\text { the requirement to engage in a two-way } \\
\text { communication }\end{array}$ \\
\hline An-Nusrah & $\begin{array}{l}\text { Assistance and } \\
\text { Solidarity }\end{array}$ & $\begin{array}{l}\text { the value of faith, hope in the assistance from } \\
\text { God }\end{array}$ \\
\hline Al-Jiddul Wal Ijtihad & $\begin{array}{l}\text { Independence in } \\
\text { thinking }\end{array}$ & $\begin{array}{l}\text { an Islamic value which underscores the value } \\
\text { of independent thinking in different situation } \\
\text { and place }\end{array}$ \\
\hline Ikhlas & Sincerity & $\begin{array}{l}\text { the Islamic value which stresses the } \\
\text { importance of sincerity or the state of } \\
\text { genuineness in any altruistic or religious act. }\end{array}$ \\
\hline
\end{tabular}

On other hand, Islamic financing modalities revolves around fixed mechanism or law in providing aid. Most MFBOs incorporate the modalities of Zakat (Islamic tithe with 2.5\% contribution), Wakaf (Islamic endowment), and Sadaqah (general donorship) in their aid financing. Similar as Islamic altruistic values, all Islamic financing modalities should be given by a provider with sincerity for the sake of Allah SWT. Table 2 provide the three critical list of Islamic financing modalities. 
DOI: https://doi.org/10.47405/mjssh.v6i3.703

Table 2: Islamic Financing Modalities

\begin{tabular}{lll}
\hline $\begin{array}{l}\text { Islamic Religious } \\
\text { Values/Modalities }\end{array}$ & Translated Meaning & Imbued principles \\
\hline Zakat & $\begin{array}{l}\text { Islamic tithe: } 2.5 \% \text { from } \\
\text { income for charity }\end{array}$ & $\begin{array}{l}\text { To ensure a justifiable distribution of } \\
\text { wealth especially to those most } \\
\text { marginalised and desperate }\end{array}$ \\
Wakaf & $\begin{array}{l}\text { Endowment: The turning of a } \\
\text { self-owned asset into public } \\
\text { endowment }\end{array}$ & $\begin{array}{l}\text { Emphasises the use of an endowed } \\
\text { asset on perpetual and non-binding } \\
\text { basis to a broad number of } \\
\text { beneficiaries }\end{array}$ \\
Voluntary Charity & $\begin{array}{l}\text { Unconditional generosity across time } \\
\text { and place which is done sincerely }\end{array}$ \\
\hline
\end{tabular}

The question broached at this juncture is - how could we potentially understand the element of faith in relations to MFBOs behaviour? Can elements of faith in Islam (Islamic altruistic values and religious financing modalities) influence the psyche or mindset and consequently the policies of MFBOs? One way of understanding this relationship is through examining Smircich organisational theory. Smircich (1983) mooted the possibility of relationship between an organisation's institutionalised culture, values, or practice - and its behavioural outcome. That being said, the key approach in situating Smircich's theory within this research is to posit all elements of faith (Islamic altruistic values and Islamic financing modalities) as the independent variables - which if institutionalised by MFBOs, can influence the latter's behaviour or policies.

The theory of Sociological institutionalism could also be utilised within this research context. One of the defining features of this theory is that - it interprets the process of institutionalisation more broadly than political scientists do, especially those from the rationalist school (Hall \& Taylor, 1996, 947). Here the sociologist defines institutionalisation happens not only through rules or policies that are formal (tangible), procedures (SOP's), or norms - but other intangible factors too such as cognitive scripts, symbol systems, and moral templates that provide the 'frames of meaning' in guiding human action or organisational behaviour.

\section{Methodology}

I adopted the qualitative strategy to analyse the perception of MFBOs policymakers on related religious elements institutionalised (altruistic values and religious financing modalities) and secondly, how it affects their organisational interaction behaviour or policy towards aid recipients. The qualitative approach is necessary given it is both flexible and interpretive, making it useful in this fieldwork (Creswell, Hanson, Clark Plano \& Morales, 2007; Patton, 2014).

In this study, I interviewed 13 individuals from 7 MFBOs. Respondents are selected from Aman Palestin, Aqsa Syarif, Majlis Perundingan Pertubuhan Islam Malaysia (MAPIM), Cakna Palestin, Muslim Care, Islamic Relief, and Haluan. I enquired all respondents about Socio-Economic projects that are implemented by their organisation from 2009 to 2020 in Gaza. The list of projects are presented in Table 3.

To extract the data, semi-structured research interviews are employed. There are two sections in the semi-structured interviews which are A and B, respectively. Part A of the semi-structured interview aims at exploring the type of religious values that MFBOs participants opined to be the most relevant and institutionalised as part of their organisational policy. To start a discussion with participants, I provided four options (related religious elements) for them to select and explain. In-line with the exploratory philosophy, I also empowered participants to provide other different religious elements deemed critical to their organisational policy. It is worth noting, during my fieldwork, this approach yielded some religious values that previously I did not expect to exist or to be useful. Part B of the semi-structured research interview aims at further exploring nominated religious elements in Part A, 
especially through the perception and opinion of interviewees. This aspect involves asking why selected elements are important and how these elements influence their respective MFBOs policy towards recipients. I adopted the manual approach to thematic analysis. In specific, the thematic approach (Braun \& Clarke, 2006) was used to analyse participants' feedback and perception in Sections A and B. The process of analysis narrowed into data that specifically suggested the influence of religious elements on MFBOs policies from the perspective of autonomy and democratic interactions. This specific type of data is identified, coded, and consequently turned into themes. Synthesised data are compartmentalised within the four socio-economic project cycles of planning, evaluation, implementation, and evaluation.

Table 3: Socio-Economic projects by MFBOs

\begin{tabular}{lll}
\hline MFBOS & Projects & Year \\
\hline MyCare & Microcredit-Qardhul Hassan Project & 2015 (Ongoing) \\
MyCare & Sponsorship of affected families & 2015 (Ongoing) \\
MyCare & Iftar Ramadan, Zakat, food parcels and Eid gifts & 2013 \\
MyCare & Cattle Livestock Program/Aquaponics & 2016 (Ongoing) \\
Haluan & Iftar Ramadan, food parcels and Eid gifts & 2013 \\
Aman Palestin & Solar Projects for Agriculture Cultivation & 2019 \\
MAPIM & Water Cells for Agriculture \& Public utility & 2016 \\
HALUAN & Micro-Credit Program & $2009-2010$ \\
MAPIM & Green House Project for Agriculture & 2013 \\
Muslim Care & Bread Factory & 2011 \\
Islamic Relief & MySadaqah for various Socio-Economic Projects & 2011 (ongoing) \\
Cakna Palestin & Back 2 School assistance for school kids & 2016 (On-going) \\
Cakna Palestin & Iftar Ramadan, Aidil-Adha, food parcels and Eid gifts & 2010 (On-Going) \\
\hline
\end{tabular}

\section{Results}

\section{Project Planning}

The common religious value often argued as being institutionalised during project planning is the notion of Musyawarrah. In its simplest understanding - Musyawarrah is an Islamic concept which defines two way-discussion between parties. Two themes are developed pertaining to Musyawarrah. The first pertains to the way Musyawarrah encourages collective discussion (Respondents 2, 3, 4, 8, 9 12 \& 13). In specific, Musyawarrah motivates the MFBOs sector to include various stakeholders during the initial planning stage. For instance, R2 and R3 stated apart from Malaysian development experts and medical practitioners, Palestinians especially students in Malaysia have been brought into their organisation's Musyawarrah process. The two respondents agreed students provide candid information especially on the social aspect in the region including the condition of their families. While R4 said through Musyawarrah, Ministries in Gaza are invited to partake in the planning and decision-making process on Humanitarian and Development assistance. Another respondent R8 echoed a similar sentiment. However, he added the concept of $\mathrm{Ta}$ 'amul apart from Musyawarrah. For the record, this concept is not within the options provided to the specific respondent to choose from. Upon research, I discovered Ta'amul here means the Islamic approach of taking views of the majority into any decision-making process. According to R8, this is the core aspect of Musyawarrah. In addition to Ta'amul, R8 also quoted an oral tradition or Hadis (Saying) from the Prophetic tradition i.e. Nabi Muhammad (SAW) 'Wa Antum A'lamu bi Amri Dunya-kum' which means 'You know more about your worldly dealings'. Relating to this tradition, the R8 argued his organisation considers the insights of the Palestinians during Musyawarrah as primary given their direct experience on the ground in Gaza. Hence this aspect itself makes their participation critical. Another Respondent i.e. R9, informed generally how the 'Participatory Approach' through Musyawarrah is embraced in his organisation. This respondent underscored the importance of beneficiaries in a Musyawarrah especially Palestinians, in making key decisions. 
The second theme suggest Musyawarrah is a flexible platform for decision making but with conditions (Respondents 4, 7, 8, $12 \& 13$ ). For R4, the basic principle of Musyawarrah is to be flexible to both parties. What he meant in this context, the need to fund any desired projects by Palestinians must be balanced with the interest of his organisations and the availability of money. As for R7, he informed once a proposal is forwarded to his organisation, the cost and benefit analysis will be conducted. Say if the outcome suggests the projected cost is higher than the available budget cycle, a counterproposal will be broached by his organisation. In this sense for R7, flexibility can be curtailed by funding limitations and project practicality.

R8 reiterated similarly. For R8's organisation, through Musyawarrah, Palestinian recipients are indeed provided with the freedom to both plan and decide projects that suit certain socio-economic context. Nonetheless, this is still largely based on funding availability in his MFBO. For R12 and 13, the needs of the Palestinians are constantly given the upmost priority. But any request must be within their organisation's financial means. If a given project is not within their financial capacity - R12 and 13 organisation will likely counter-propose with a different project. Nonetheless as stressed by R12, any new project must be agreeable by the Palestinians themselves.

\section{Project Financing}

For most respondent, the common financing modality institutionalised during the funding of any socio-economic projects revolves around the Sadaqah approach. Sadaqah is an Islamic way of defining the giving out of money for altruistic purposes. Given this argument, I have developed two themes pertaining to sadaqah.

The first theme relates to the ease in organising the protocol of collecting Sadaqah (Respondent $1,2,3,4,5$ and 9). Before moving forward, one should note 'ease' here does not mean sadaqah as a tool which facilitates a generous collection; rather ease here refers to the process of organising the collection of money. For example, R1, R2 and 3 argued through the use of 'Sadaqah 'brand, it allows their organisation to distribute donation boxes in various location. R1 specifically told me his organisation's Sadaqah donation box has been distributed in restaurants, mosques, corporate organisations and airports. However, R1 added despite having this flexibility, a need in explaining the overall motive of the Sadaqah, still exist. Explanations are usually attached on the Sadaqah boxes through sticker labels.

R1 also stated his organisation coordinate the collection of Sadaqah through online means via MAPIM's online Tabung dana kecemasan Gaza (donation for emergency purposes in Gaza) webpage(https://www.billplz.com/tabungkilatgaza). However, being traditionalist himself, R1 personally prefers the offline strategy. He listed a key reason to this phenomenon. To him, within the cyber context, there is no real face to face interaction to effectively lobby for project funding. Despite this shortcoming, he still underscores the online method to an extent. To R1, this approach 'adds to the arsenal' in terms of MAPIM's fund raising strategy. R4 and 5 also informed me the general nature of sadaqah which allows their MFBOs to also coordinate sadaqah collection via online means. R4 and 5 informed me any potential new socio-economic projects in Gaza can be promoted via their organisations Facebook or twitter page. It is a usual practice for project promotion to be accompanied with plea to donate for such projects. While R9 stated through capitalising the generality of Sadaqah his organisation organises an online sadaqah channel i.e. MySadaqah program (https://islamicrelief.org.my/others/mysedekah/). To date, money derived from various donors around the world are utilised to fund emergency and ongoing socio-economic projects. As detailed by R9, recipients in Gaza and West Bank have benefited from My Sadaqah in the past. Online research confirms Gaza and West Bank to be some of the regions where MySadaqah project is focusing on.

Sadaqah's condition in accepting any amount of donation is also a key factor that eases MFBOs fundraising initiative. As observed by all interviewees, there is no minimum or maximum amount required when it comes to fundraising from individual donors - especially if this type of sadaqah is collected via donation boxes. I have also observed such conditions applied in fundraising events. A donor may donate as low as 20 cents, in principle. Given this less taxing approach, sadaqah 
encourages the behaviour of micro-donating. R1 described this to me, as the non-stop behaviour of small donation made by Muslims especially in Mosques and Muslim restaurants. This repeated behaviour in-turn produces the trickle effect of small money received from time to time. In his own words 'kesan berulang dalam memberi sedekah kecil dari semasa ke semasa'.

The phenomenon of anonymous donors is the second theme I developed from MFBOs participants feedback (Respondent 1, 5, 6, 9 \& 13). R5, R6 and R13) informed me that anonymous sadaqah donors, in essence (Penderma tanpa nama) does not reveal their names, or stipulate the exact use to their money donated. A few logics to the existence of anonymous donors will be broached. For some Muslim donors, anonymity and non-conditionality is sacred. Prevailing believe suggests it shields one from a sense of pride, arising from donating openly in public. Such approach protects the purity of intention. Being anonymous may also protect their sense of being genuine or Ikhlas in Arabic. This is to ensure the act of donation is done solely with the intention of pleasing God (Allah SWT). However, the most convincing explanation to this phenomenon can be derived from the religious script of AlQuran, Surah Al-Baqarah (14-2) which offered the promise for transcendental reward by Allah SWT (Tsawab) for those who donate in secrecy. I argue this saying plays a strong influence to Muslim psyche when it comes to giving out sadaqah.

There are few implications worth discussing. R1 argued money from anonymous donors are generally rendered to recipients with no fixed conditions, since the sadaqah money itself, is given without any conditions from the anonymous donor. Despite this flexibility, it is still compulsory for recipients to report the usage of such money for projects. Report is usually prepared by recipients at least once a year. R1 stated his MFBOs previous socio-economic assistances using money from anonymous funding has allowed recipients to independently develop food bank projects and provide general aid to orphans. The similar participant narrated a situation in 2004, where a water tank in a Gaza Christian Church was repaired using money directly from anonymous donor's funding.

While R5 and 6 informed me Aman Palestin anonymous money is usually channelled for emergency purposes. An example is seen through the creation of emergency funding for Aman Palestin recipients. This type of emergency funding has been deployed to its recipients after the Protective Edge war. The 2014 conflict was fought rather bitterly between Israel and Hamas. Thousands of Gazans killed and there were massive destructions on the farmlands in rural Gaza. According to R5 and 6, funding derived from anonymous donors is immediately disbursed by the Aman Palestin's headquarters in Gaza to grass-root recipients. A Cakna Palestin participant informed the organisation distinguishes some Sadaqah's received as Sedekah Umum (general sadaqah). Here general sadaqah is obtained from unnamed donors or donors who don't stipulate specific use out of their contribution. For $\mathrm{CP}$, in the absence of definite condition from primary sadaqah donors, this scenario allows $\mathrm{CP}$ to independently decide the type of assistance required by the Palestinians. I was informed, in certain instances, CP also gives Palestinians the space to request money from the general sadaqah fund, if emerging needs, do arise. However, the approval of such request still depends on the amount available in this fund.

On other hand, R9 informed me of an internal fatwa (Islamic legal decision) in his organisation which allows the distribution of sadaqah to non-Muslims when it is sourced from anonymous donors. In this light, R9 added the concept Rahmatan-Lil-Alamin (mercy to all mankind, including non-Muslims) as the key value that motivates his MFBOs to pursue such interaction. It is worth adding, this concept is not within the options provided to the respondent to choose from.

Project Implementation

According to respondents, two religious values deemed critical during project implementation revolves around the notion of Al-Jiddul - Wal Ijtihad or Ijtihad and Amanah. Within the Islamic theological argument, Al-Jiddul - Wal Ijtihad or Ijtihad means the process of using one's intellect independently in making decision. This decision is judged best and fair based upon available information or resources at a given particular time. While Amanah revolves around the idea of being trustworthy or credible. 
The thematic discussion on Ijtihad centres around the complex situation in Gaza and recipient's broad autonomy in decision making (Respondents 1, 2, 3, 4 5, 6, 8, 10 \& 11). For R1 and R2, ijtihad is usually given to recipients since Gaza constantly face political insecurity. Blockade causes Gazan to face with limited options and resource. Hence R1 opined, his organisation's recipients must be empowered to make decisions deemed suitable during project implementations. R1 goes to state given if his recipient's ijtihad requires the smuggling of important Humanitarian materials from any tunnels (bordering Gaza and Rafah in Egypt), this effort will be allowed. R5 and R6 suggested the same argument. In this this context, if their recipients are forced to smuggle aid through the tunnel, this aspect is allowed. For these two respondents, this is the ijtihad of the recipient must make. It is worth noting, tunnels are deemed illegal by the United States, Egypt, and Israel.

R3 echoed a similar sentiment. He believed since Gaza is under Israel's land siege and the latter's constant military attack, the decision-making process must be decentralised to ensure recipients survival. R4 opined, their recipients are given autonomy to make any best decision during implementation. In this context, R4 stressed "Penerima dana digalak untuk mengutamakan pendekatan kepelbagaian cara dalam membuat sebarang keputusan atau menyelesaikan masalah berkait implementasi di Gaza" (recipients are encouraged to explore various methodology in solving problems during project implementation). R8 provided the same feedback. The complex situation in Gaza requires some form of independence in decision making for recipients. However, he also underscored the critical aspect of informing his organisation prior to any decisions being made. Continuing with the theme of autonomy in decision making, both R10 and R11 stated that recipients are given the "hak bertindak" or "the right to act' in making the best decision. Given recipients in Gaza are facing the reality of blockade, they would have a better understanding of how to solve emerging issues during project implementation.

\section{Project Evaluation}

Respondents perspective are largely concentrated on Fikh Aula-Wiyat and Husnuzhon as the two most applied altruistic religious values during their organisational evaluation stage. Fikh-Aula-Wiyat means - the prioritising of the best approach in solving any given problem. It is worth noting Aula is an Arabic notion which can be interpreted as 'better'. While Husnuzhon means to inculcate a positive perception or a perhaps fair view on others, especially if there are any initial hiccups or problem faced.

Two separate themes are generated for Fikh Aula - Wiyat. The first set of argument from respondent 3, $8,12 \& 13$ suggested the interpretation of Fikh Aula - Wiyat as a policy which inculcate both a less structured evaluation and immediate project completition. For instance, R3 argued, instead of enforcing strict project specification and implementation - the primary objective of aid assistance should be about reducing or mitigating the critical situation in Gaza within the shortest time-frame. This is the aula approach for R3. His MFBO also focuses on 'what additional aid that might be needed' by recipients. What he meant in this context is the functional aspect of the project. It is considered enough, if any infrastructure built, is able to serve its basic function. R3 opined being pedantic in measuring the various dimensions to ensure sponsored infrastructure is within previously agreed specifications, is not helpful.

While R8 stated, socio-economic projects are meant for Palestinians. Palestinians are the ones that will utilise the final product. Being rigid is no use. It puts an unwarranted burden onto recipients. In the scenario where mistakes are evident (e.g. a few housing projects which may not correspond with a previously agreed dimensions), his organisation will solve the issue immediately. It is not to their interest to drag any technical issues. To him, the main aim is to expedite project completion, so as it will benefit Palestinians immediately. The respondent, however, stressed that recipient still need to inform his organisation of any mistakes or changes in plan for the sake of documentation. R12 and 13 echoed a similar sentiment. Respondents argued on the immediate need for project completion. The approach is not about ensuring the $100 \%$ accomplishment of a given project as required. The focus shall be on the completion of the project within the shortest time frame. 
Finally, themes generated for Husnuzhon (an Islamic value which encourages fair views on others) revolves around both flexibility and trust (Respondent 1, 10, and 11). R1 stated that if a recipient cannot execute a project wholly as agreed - his organisation as much as possible, would try to avoid prejudices. To R1, project evaluation should be flexible within the existing constraints in Gaza. If the final implementation is within $80 \%$ of what initially has been agreed-R1's organisation may still accept the project. R1 gave an example where his organisation once sponsored a greenhouse project for agriculture. Towards the end, the greenhouse was not built according to specification. R1's organisation accepted the project with conditions. I was informed by R1 that his MFBO in that instance, requested the recipient to draft a feedback on the specific reasons as to why the project is unable to be completed as planned. The feedback is then forwarded to funders for their consideration.

R10 and R 11 stated that Husnuzhon is translated into the trust given to the locals in executing the project. Locals are perceived to have a good understanding of the situation. A key information that is passed on to the researcher is also that - there is no condition in their MFBO contract which defines the need for any evaluation. In this case, all tasks for evaluation are entrusted to their recipients in Gaza.

\section{Discussion}

The analysis gives us initial insights on the influence of 'elements of faith' onto the psyche and the policies of the MFBOs sector. For clarity, I extracted four critical points (from all themes) highlighting how 'element of faith' influences interaction within the stages of project planning, financing, implementation and evaluation. These points are obtained from respondents' perspective on their MFBOs policies.

\section{Musyawarrah leads to collective participation during Planning}

The common religious value argued as being institutionalised during project planning is the notion of Musyawarrah. A key theme developed on Musyawarrah pertains to collective participation. I discovered MFBOs inculcate an inclusive and collective approach of discussion when it comes to initiating the Humanitarian and Development effort. This approach leads to usually broad participation amongst various stakeholders within the Palestinian community, i.e. grass-root and the public sector. For the grass-root sector, I observed NGOs both affiliated and non-affiliated to Hamas are commonly consulted by MFBOs to get a better perspective on the type of socio-economic projects needed. For instance, MFBOs communicate with Tajammuq which is a Government affiliated NGO in Gaza to discuss on agriculture related projects in Gaza. Students are also included during project planning, especially if it is done in Malaysia. As mentioned earlier - students provide candid information especially on the social aspect on the region.

\section{The utility of Anonymous Sadaqah money leads toflexible financing}

The Sadaqah approach is perceived to be one of the most critical financing modalities institutionalised. There are few observations to the utility of sadaqah. First, the use of the Sadaqah modality for fundraising - encourages donors and, in certain cases, the majority of donors for some MFBOs, to donate money on a private basis. This donor does two things in the process, i.e. (1) they avoid revealing their names, and (2) such donor avoids stipulating conditions. The afore-mentioned donating behaviour, however, has a bottom-line. In essence, such an approach provides the leverage for MFBOs to be flexible towards recipients.

Some MFBOs argued money from anonymous donors are usually rendered to recipients with no conditions, since the sadaqah money itself, is donated without any conditions from the primary donor. I was informed nonetheless; it is still compulsory for recipients to report the usage of such money for projects. Project reports will be published in MFBOs website or social-media accounts. 
A participant stated his MFBOs previous socio-economic assistances using money from anonymous funding allowed recipients to independently develop food bank projects and provide general aid to orphans. The similar participant narrated a situation in 2004, where a water tank in a Gaza Christian Church was repaired using money directly from anonymous donor's funding.

With no conditions from anonymous donors, it also provides MFBOs with certain leverage to create projects that reflect the reality or needs of recipients on the ground. This is the case for emergency funding created by Aman Palestin (AP) through the use of anonymous donors' money. Earlier, we discovered, AP utilised this funding to immediately mitigate its damaged agricultural land, after the 2014 Hamas-Israel war. Flexibility is also seen when Islamic Relief allows the distribution of anonymous sadaqah to Christians when it is not specified in its use.

For Cakna Palestin (CP), in the absence of definite conditions from primary sadaqah donors, this allows it to independently decide the type of assistance required by the Palestinians. As mentioned earlier, CP also gives Palestinians the flexibility to request money from the general sadaqah fund, if emerging needs, do arise. My final interview with a MyCare official also suggested the use of anonymous sadaqah funding eases the process of allocating money, especially on aid that is required by Palestinians in Gaza.

\section{Ijtihad and Autonomy during implementation}

The inculcation of ijtihad is argued to be most critical for MFBOs. In this context, the usage of ijtihad leads to autonomy and empowerment. I discovered MFBOs branch in Gaza (staffed by Palestinians) are provided with the ijtihad and autonomy to decide on the right type of project, including the best way of implementing it. Local ingenuity to solve impending problems is also encouraged.

In this context, I was informed of a unique situation by a recipient from Aman Palestin (AP) on how ijtihad is applied. This recipient narrated to me a scenario during the early days of constructing asphalt roads and water wells within AP's agriculture precinct in Khourzanoun (North of Gaza) - which were often halted by Israel military's random shots against Palestinian workers. This scenario retarded their ongoing project implementation. To solve this problem, his organisation in Gaza independently networked and coordinated effort with Gaza Red Cross to reach out to Israel Red Cross. The latter consequently communicated and clarified with Israel military force that AP is developing a Humanitarian based agriculture projects in Khourzanoun. At this juncture, I was informed, the outcome of the negotiation is positive. Israel military stopped its shooting.

\section{Fikh Aula Wiyat and the idea of Less Structured Evaluation}

The most important religious values for MFBOs at this stage is the use of Fikh Aula Wiyat paradigm. Through this religious value, I discovered emphasis is not given by MFBOs to its recipients to establish a strict evaluation regime, especially in assessing project impact - post-implementation period. There is also less emphasis to inculcate strict project specifications for recipients implementing projects. I will not discount however that; progress report is still required by all MFBOs from their recipients.

For the MFBO sector, the existence of Gaza sufferings and the need to solve it always take precedence over other considerations. Aid is also about reducing or mitigating such a dilemma within the shortest time-frame. Overall to most MFBOs this approach is Aula to them. In this context, prevailing sentiment suggested putting strict or pedantic evaluation processes - only increases the current burden Palestinians are facing. This path if taken, may slow down project completion. Here I observed - there is equal leeway provided if projects are not implemented in a way that would have been initially agreed. Marginal error is tolerated. This type of tolerance comes from MFBOs own understanding of the resource-stricken situation in Gaza. 


\section{Conclusion}

At a fundamental level, there is an influence of religious elements (altruistic values and religious financing modalities) in the way MFBOs sector as an entity - would perceive, rationalise, and fund recipient socio-economic projects. Research outcome suggest this form of interaction is seemingly more democratic and flexible since there is no obvious aid conditions. We should not however discount the factor of sharing the same religion between Malaysian Islamic FBOs donors and Palestinians Muslims recipients, in making this interaction more fluid. Future research should examine this angle of interaction.

Factors mentioned above nonetheless, proves the MFBOs approach is indeed different in ways Western donors, for instance, would approach their recipients. As elaborated in the literature review section, interaction is based on stringent political and economic-based conditions. In this context, Sari Hanafi and Linda Tabar argued how Western donors generally utilises conditionalities based on (1) political eligibility, (2) sectoral eligibility, and (3) professional eligibility (Sari Hanafi \& Linda Tabar, 2005), when it comes to identifying potential recipients and interacting with them.

It is worth noting, this research provides only an exploratory platform in identifying the potentiality of Islamic FBOs model as an alternative source of a more democratic aid system. Hence it is essential for an extended research to be conducted in few other aspects to strengthen this discovery. For instance, given this research is only narrowed to understand Malaysian Islamic Faith-Based Organisation (MFBOs) - there is a need to explore other Islamic FBOs in the region that is equally playing a role in Gaza. Ideally, Islamic FBOs from Indonesia, Turkey, and Qatar are some FBOs that should be explored. The second aspect worth examining is the financial impact of this sector. Indeed, this sector generally provides aid on a non-conditional basis - but in my point of view, the amount rendered is small comparatively to Western donors' annual contributions. Research must focus into finding ways in making MFBOs sufficient in their funding, especially for socio-economic projects in the region. Finally, similar attention should be given to the perception of the international community towards Islamic Faith-Based Organisation. Over the past decade, Islamic organisations are often linked with terrorism financing. The main challenge is to study the impact of such opinion and understand how it may affect the potentiality of the FBO model to be promoted as an alternative form of aid in Gaza and broader Occupied Palestinian Territories (oPt).

I argue the afore-mentioned perspective should be taken into future research to contribute towards a more nuanced understanding of the FBO sector as an alternative form of aid source for Palestinians.

\section{References}

Aktiviti dan Projek Aman Palestin. (2017, August 21). Aman Palestin. Retrieved from www.amanpalestin.net/salam.php?kategori=aktiviti_projek

Braun, V., \& Clarke, V. (2006). Using thematic analysis in psychology. Qualitative research in psychology, 3(2), 77-101.

Challand, B. (2008). Palestinian civil society: Foreign donors and the power to promote and exclude. New York: Routledge.

Clarke, G. (2008). Faith-based organizations and international development: An overview. Development, civil society and faith-based organizations, 17-45.

Creswell, J. W., Hanson, W. E., Clark Plano, V. L., \& Morales, A. (2007). Qualitative research designs: Selection and implementation. The counseling psychologist, 35(2), 236-264.

Hall, P. A., \& Taylor, R. C. (1996). Political science and the three new institutionalisms. Political studies, 44(5), 936-957.

Hammami, R. (1995). NGOs: the professionalisation of politics. Race \& Class, 37(2), 51-63.

Sari Hanafi \& Linda Tabar (2005). The emergence of a Palestinian globalized elite: donors, international organizations and local NGOs. Jerusalem; [Ramallah], Institute of Jerusalem Studies; Muwatin. Palestinian Institute for the Study of Democracy. 
DOI: https://doi.org/10.47405/mjssh.v6i3.703

More, A. L. (2008). International assistance to the Palestinians after Oslo: political guilt, wasted money, Abingdon (Oxon): Routledge.

Muslim Aid 2012 (2013, January). Annual Review. Muslim Aid. Retrieved from http://www.muslimaid.org

MyCare: About Us. (2010, Jan 1). MyCare. [Online]. Retrieved https://www.mycare.org.my/about-us/

Patton, M. Q. (2014). Qualitative research \& evaluation methods: Integrating theory and practice. Thousand Oak, CA: Sage publications.

Pertubuhan Himpunan Lepasan Institusi Pendidikan Malaysia (HALUAN). Retrieved from https://www.haluan.org.my/donations/akademigaza/.

Qarmout, T. (2017). Delievering aid without Government. Gewerbestrasse, Cham: Springer International Publishing.

Shafi, S. A. (2004). Civil society and political elites in Palestine and the role of international donors: A Palestinian view. Lisboa: EuroMeSCo Secretariat.

Smircich, L. (1983). Concepts of culture and organizational analysis. Administrative Science Quarterly, 28(3), 339-358.

Staff (2019). 'USAID to lay off $85 \%$ of local staff as aid to Palestinians is cut', Times of Israel 18 April, viewed 25 September 2019, < https://www.timesofisrael.com/usaidto-lay-off-85-of-localstaff-as-aid-to-palestinians-is-cut-report>

Taghdisi Rad, S. (2015). Political economy of aid in conflict: An analysis of pre-and post-Intifada donor behaviour in the Occupied Palestinian Territories. Stability: International Journal of Security \& Development, 4(1), Art-22.

Trump and the Palestinians: A timeline (2019, Nov 19). Al-Jazeera News Middle East. Retrieved from https://www.aljazeera.com/news/2019/11/19/trump-and-the-palestinians-a-timeline 